\title{
RBFネットワークを用いた時間帯別入込人口 推計のダウンスケーリング手法の開発
}

\author{
生越 拓実 1 有村 幹治 2 ・浅田 拓海 3 \\ 1学生会員 室蘭工業大学 大学院工学研究科 環境創生工学系専攻（率050-8585 室蘭市水元町27-1） \\ E-mail: 16041014@mmm.muroran-it.ac.jp \\ 2 正会員 室蘭工業大学准教授 大学院工学研究科 くらし環境系領域（广050-8585 室蘭市水元町27-1） \\ E-mail: arimura@mmm.muroran-it.ac.jp \\ 3 正会員 室蘭工業大学助教 大学院工学研究科 くらし環境系領域（ $\bar{T} 050-8585$ 室蘭市水元町27-1） \\ E-mail: asada@mmm.muroran-it.ac.jp
}

\begin{abstract}
近年，コンパクトシティ政策等の都市施策に関する計画情報の一つとして，マイクロジオデータの活用 が注目されている。本研究では，モバイル空間統計および都市計画基礎調查の 2 つのマイクロジオデータ を統合的に用い, RBF ネットワークにより, 空間的な分析解像度をダウンスケールしながら時間帯別入込 人口を推定する手法を開発した。具体的には，3 次メッシュスケールで集計した建物用途別延床面積から 各メッシュの入込人口を推定するモデルを構築し, そのモデルを用いて, 4 次メッシュスケールでの入込 人口推計を行った. 本手法により得られた詳細な入込人口分布を空間的に可視化することで, 3 次スケー リングでは困難であった細かい箇所毎の入込人口分布を把握することが可能となった.
\end{abstract}

Key Words : compact city, mobile spatial statistics, basic survey of city planning, RBF network

\section{1. はじめに}

我が国が抱える問題の一つとして少子高齢化がある. 2016 年 3 月では 1 億 2692 万人であった人口は今後減 少していき, 国立社会保障・人口問題研究所によれば, 2036 年には死亡・出生中位仮定において 1 億 1117 万人, 2056 年には 9090 万人にまで人口が減少すると予測され ている ${ }^{1)}$.このような社会・経済情勢変化に応じた持続 可能な都市構造への再構築の方策として, 都市の中心 部に住宅や公共施設，商業施設など様々な機能を集約 し，徒歩や自転車，公共交通で移動しや寸い環境を創 出しつつ市街地を集約する「コンパクトシティ・プラ ス・ネットワーク施策」がある。このような施策を地 方都市において検討する際には，例えば，どの種別の 都市施設や建物を, どの規模で, どの地区に集約させ るべきか, そして，その結果，どの程度の賑わい，す なわち人の入込を創出できるかを検討する必要がある. その検討材料の一つとして, 現状における入込人口と 建物立地の関係，さらには，新たな都市構造を想定し た場合の入込人口の空間的分布を予測することが重要 となろう.

一方, 近年では諸都市の状況に応じた計画情報を得 るため, マイクロジオデータの適用が期待されている.
マイクロジオデータを用いた人口予測に関する研究事 例としては, アンケート調查結果から生成した個人・ 世帯のマイクロジオデータによりライフイベントの発 生に伴う世帯構造変化や移住地の変化加ら将来人口分 布を予測するモデルを構築した鈴木ら 2,3)の研究がある. また, 郊外ニュータウン地域を対象に, アンケート調 查結果による世帯のマイクロジオデータから居住世帯 数の将来予測を行った杉木ら ${ }^{4)}$ の研究などがある. これ らの研究成果から, 居住人口の将来予測へのマイクロ ジオデータの有効性が示されているところだが，細か い時空間単位で動的に変化する「入込人口」を分析対 象とした事例は少ない，その点に着目し，著者らは， 複数のマイクロジオデータの統合化による入込人口の 推計を行っている. 具体的には, NTT Docomo ${ }^{5}$ )が提供 寸る「モバイル空間統計」から得られるメッシュ毎の 入込人口を目的変数, 「都市計画基礎調查データ」の 建物用途別延床面積を説明変数として重回帰分析を行 い，入込人口に影響を与える建物用途を明らかにした ${ }^{6}$. しかし, この研究では, 重回帰分析が用いられたこと で, 統計的に有意な建物属性のみが説明変数として採 用され，他の多くの属性が破棄されてしまい，メッシ ユ内の建物属性の相互作用が考慮されず，推定精度に 限界があったこと, また入込人口データが 3 次メッシ 
ユの規模で得られるため, 都市計画基礎調査データに は建物毎の詳細なデータが収録されているにも関わら ず, 推定結果が 3 次メッシュレベルに留まり, 空間分 解能が低かったこと，以上の 2 つが課題となっていた。

そこで, 本研究では, 入込人口の推定精度向上を目 的に RBF ネットワークを導入し, 先ず 3 次メッシュス ケールでの建物属性データと入込人口データを学習用 データとした入込人口推定モデルを構築する.これに より特定の建物属性のみではなく, メッシュ内の全て の建物属性の構成パターンに応じた入込人口を推定で きる．また，学習済みの RBF ネットワークモデルを用 いて, より詳細な 4 次メッシュスケールにおける入込 人口の推定手法を検討する.

本研究の構成は, 以下の通りである. 第 1 章では, 本研究の背景と目的を述べる. 第 2 章では, 対象都市 の概要および分析に使用したモバイル空間統計と都市 計画基礎調査の 2 つのマイクロジオデータについて説 明する. 第 3 章では，上記 2 つのデータを用いた時間 帯別入込人口の推定モデルを構筑するとともに，その 空間的な分析単位をダウンスケーリングする手法を考 案し, 適用結果から本手法の妥当性を検証寸る. 最後 に，第 4 章で結論を示す.

\section{2. データの概要}

\section{(1) 対象地域}

分析の対象地は，著者らの先行研究 のと同様に，地方 中核都市であること, 平地かつ周辺の都市の影響が少 ないこと，また市街地形成が基盤目状になっており建 物の分布を把握しやすいことから, 帯広市を中心に, 都市構造を形成している音更町, 幕別町, 芽室町を加 えた 1 市 3 町の帯広都市圈をケーススタディとした.

帯広都市圈は北海道東部の十勝平野に位置し, 現在 は人口約 25 万人の地方中核都市である. 都市圈の中心 の帯広市の人口は少子高齢化によって2000年をピーク に減少期を迎えていること，また音更町はベッドタウ ン化による宅地開発の影響で人口と人口増加率の二つ が増加していることから, 帯広都市圈は将来的に人口 構造や都市機能の変化が想定される地域である.

\section{（2）都市計画基礎調査データによる建物用途別延床面積 の集計}

都市計画基礎調査は，都市計画区域の現状及び将来 の見通しを把握するために，人口や産業，建物など国 土交通省令で定められる項目について約 5 年毎に実施, 更新される. 近年では, 調査成果のデジタル化が進め られ, 建物の用途, 構造, 建築面積, 延床面積などの

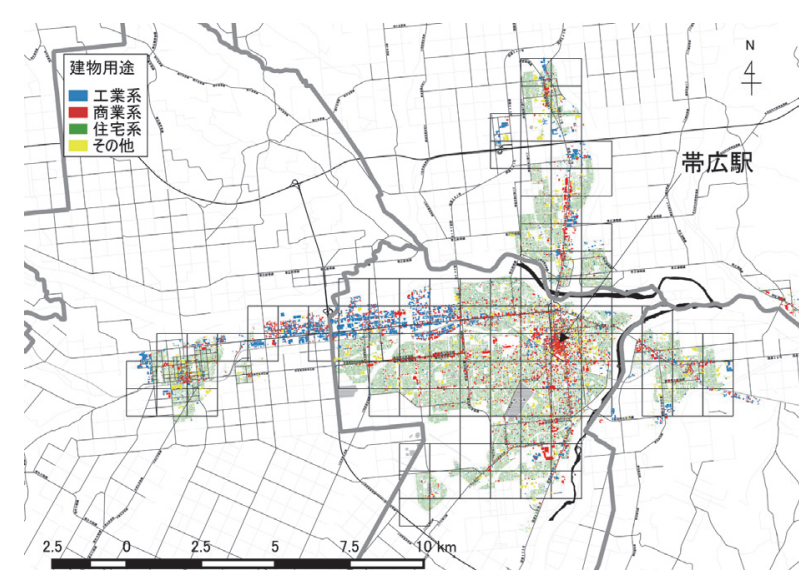

図-1 带広都市圈における建物分布

表-1 分析に用いた建物用途

\begin{tabular}{|c|l|}
\hline 大分類 & \multicolumn{1}{|c|}{ 小分類 } \\
\hline 商業 & $\begin{array}{l}\text { 地方国家施設, 自治体施設, 業務施設, 集合販売施設, } \\
\text { 宿泊施設, 興業施設, 風俗営業施設, 遊戯施設, スポー } \\
\text { ツ施設, 専用店舗施設 }\end{array}$ \\
\hline 住宅 & $\begin{array}{l}\text { 専用住宅, 共同住宅, 一般店舗併用住宅, 事務所併用住 } \\
\text { 宅, 飲食占併用住宅, 作業所併用住宅 }\end{array}$ \\
\hline 工業 & $\begin{array}{l}\text { 重化学工業施設, 軽工業施設, サービス工業施設, 家内 } \\
\text { 工業施設, 供給処理施設, 運輸倉庫施設, 通信施設 }\end{array}$ \\
\hline その他 & $\begin{array}{l}\text { 教育施設, 文化施設, 宗教施設, 医療施設, 運動施設, } \\
\text { 社会福士施設, 厚生施設, 農業施設 }\end{array}$ \\
\hline
\end{tabular}

情報が収録されており，都市政策の企画・立案及び都 市計画の運用に資するため，土地利用現況，建物現況， 都市施設, 市街地整備の状況等についてデータベース の構築が積極的に進められている7).

本研究では, 平成 21 年度帯広都市圈の「都市計画基 礎調査データ」を使用する. 対象地域における建物分 布を図-1 に示寸.JR 帯広駅を中心に商業系建物が集ま り, その周りには住宅系建物が広く分布している. 工 業系建物は，帯広市の北西部に集まり，それ以外では ほとんど見られない。同じ系統の偏りが見られるもの の, それらの中に他の系統や系統内の多様な建物が混 在しており，エリア毎に色合いが異なっている．本研 究では, 上記のように混在する建物用途の延床面積の パターンから入込人口を推定できると考え，以下に説 明する「モバイル空間統計」と同じ 3 次メッシュ単位

（図-1）で集計してデータセットを作成した，入込人口 の推定に用いた建物用途を表-1 に示す。これらは, 帯 広都市圈の都市計画基礎調査データの建物用途コード 分類表における 34 の小分類であるが，そのうち 3 分類 (記念施設, 漁業施設, 研究施設) は対象都市内にほ とんど存在しないため, これらを除外した 31 の分類を 分析に用いた。 


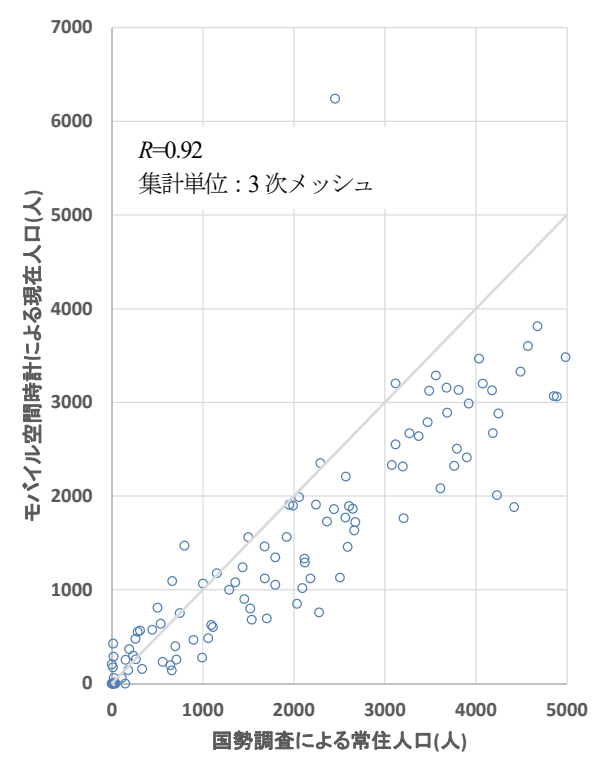

図-2＼cjkstart国勢調査による常住人口とモバイル空間統計 による現在人口（深夜帯）の関係の

\section{(3) モバイル空間統計による入込人口推計}

「モバイル空間統計」とは，NTT Docomo の携帯電話 ネットワーク運用データを用いて，エリア別にある時 間に滞在している人口（以下，現在人口）を推計した ものであり, 細かい時間帯別の人口分布を動的に捉え ることができる新たなデータとして近年注目されてい る. 現在, 我が国の総人口約 1 億 2700 万人に対し, 携 帯電話 3 社全体の契約者数は約 1 億 6300 万件に達し,

NTT Docomo の携帯電話の契約者数は 7000 万件と全体 の 4 割以上を占める ${ }^{8}$. このような携帯電話の高い普及 率と NTT Docomo の大きなシェアから, 信頼性の高い 現在人口分布を得ることができる.このモバイル空間 統計の信頼性については, 著者らの先行研究 のにおいて, 国勢調查（常住人口）を一つの参考值として比較・検 証している. 本研究では, 常住人口ではなく, 現在人 口の推定を目的としており，また，モバイル空間統計 と国勢調查では集計・推計方法が異なるため, 必ずし も人口の值は一致しないが，両者の間に高い相関 $(R=0.92)$ があることが確認済みである（図-2）。なお， 現在人口が常住人口よりも大幅に大きい点は, 当該义 ッシュの局所的な特性（駅前の大きな歓楽街を含む） が影響していると考えられる。

本研究では, 上記の帯広都市圈における建物分布があ る範囲を網羅する3次（110メッシュ）および4次（372

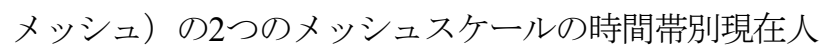
ロデータを用いる. 3次スケールは現在人口の推定モデ ル構築に用い，4次スケールはそのモデルによるダウン スケール結果の精度検証に用いる. 両データともに, 現在人口の検出日時は，平成 25 年 10 月 23 日（平日）の2

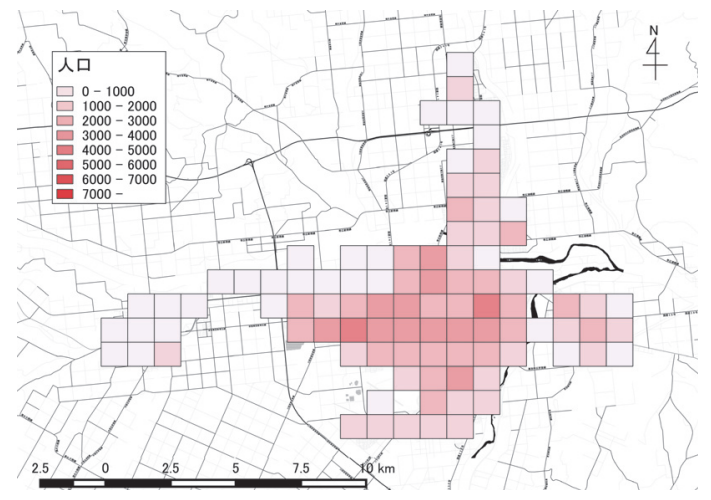

図-3 2 時における現在人口の分布

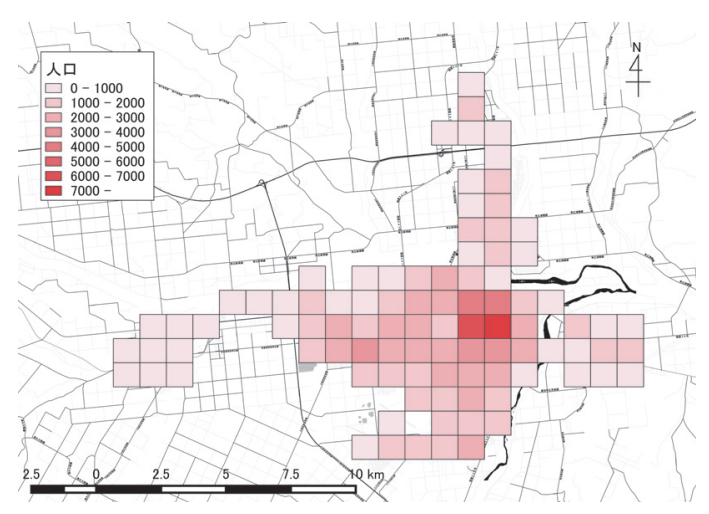

図-4 10 時における現在人口の分布

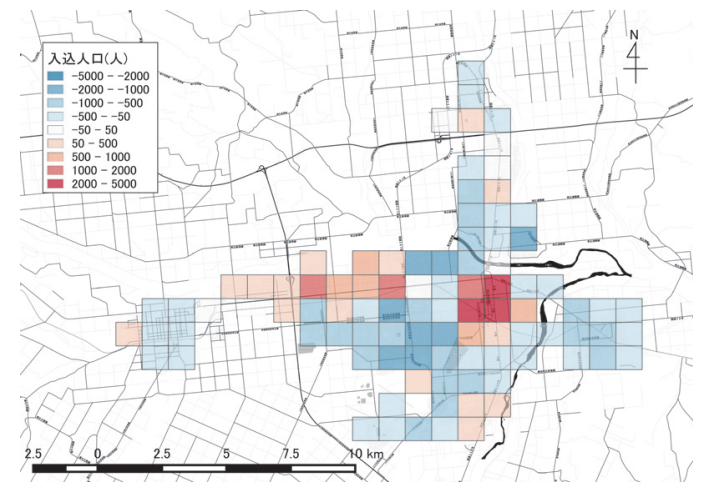

図-5 10 時における入込人口の分布

時と10時である.

対象時間帯における現在人口の分布を図-3, 図-4に 示す，両時間帯ともに，商業系建物が多いエリアに現 在人口が多く, 特に JR 帯広駅周辺で顕著である. 深夜 帯の 2 時から午前の 10 時になると，JR 帯広駅を中心之 してより狭い商業系エリアの現在人口が大きく増加す ることがわかる。一方，それ以外の住宅系建物が多い エリアでは, 現在人口の増減は小さい.

上記のように深夜時間帯の現在人口からの差分を取 ることで，対象時点における「入込人口」として考え ることができる. 2 時と 10 時の差分，すなわち 10 時に 
おける入込人口の分布を図-5 に示寸，上述した商業系 地域等での現在人口の増加を含め, メッシュ毎に人の 移動を把握できる.

\section{3. 入込人口推定モデルとダウンスケーリング手 法}

本章では，都市計画基礎調査による建物用途別延床 面積データから入込人口を推定するモデルを構築し， さらに，より細かい空間単位での推定を可能とする夕゙ ウンスケール手法について検討寸る．具体的には，ま ず，3次スケールのデータを用いて，RBFネットワーク による入込人口推定モデルを構築する. 次に，そのモ デルの適用範囲を工夫することにより，4次スケールで の入込人口を算出する手法を開発する.

\section{(1) RBFネットワークの概要}

RBFネットワークは, 有限個の入出力データを補完す る方法として提案されたニューラルネットワークの一 つであり, 入力層, 中間層, 出力層の3層から構成され, 中間層にあたる複数のRBF（放射基底関数）に重みをも たせ足し合わせることにより，任意の非線形関数の近 似が可能である9. さらに，最小二乗法によって任意の 非線形関数の最良近似法を導くことができるという特 徵がある.

$\mathrm{RBF}$ ネッワークは, 多層パーセプトロン等でよく挙 げられるローカルミニマムの問題が無く, 最小二乗法 によって任意の非線形関数の最良近似法を導くことが できるという利点を有する．また，シグモイド関数型 のニューラルネットよりも中間層の数を少なく設定で きるなど, 構造の簡素化により学習効率の面でも優れ ていると報告されている10,11)，RBFネットワークの概念 を図-6に示す．RBFネットワークは有限個の入出力デー タを補完する方法として提案されたニューラルネット ワークである. 入力層, 中間層, 出力層から構成され, 中間層にあたる複数のユニット，すなわち放射基底関 数（以下, RBF : Radial Basis Function）に重みをもたせ 足し合わせることによって，任意の非線形関数の近似 が可能となる. 図-6に示したように，N個の有限入出力 データの組, $\left(x_{1}, y_{1}\right), \cdots,\left(x_{n}, y_{n}\right)$ が与えられたとき, これら を満たすような関数 $y=f(x)$ を同定するために, RBFによ る非線形近似を適用寸る9)。なお，中間層の放射基底関 数としては, ガウス関数, Multiquadric, 薄板スプライ ンなどを設定できるが，本研究では，一般的かつ最も よく採用されるガウス関数を用いることとした.

メッシュ内の建物属性データから入込人口の推定に RBFネットワークを適用寸る利点は，構造が簡素であり，

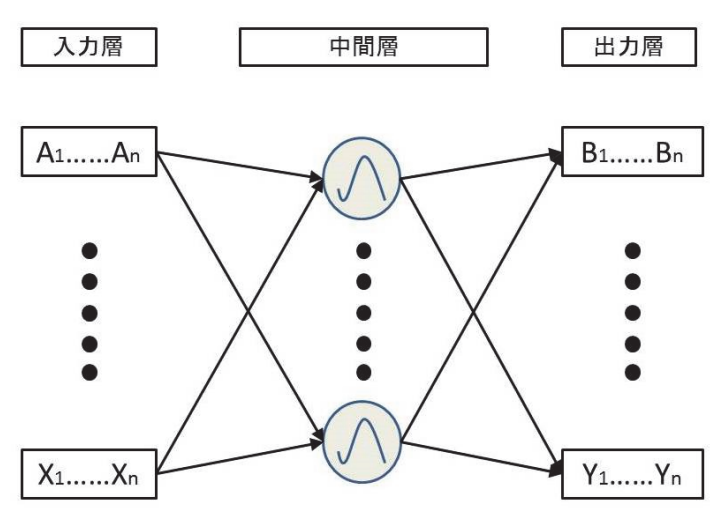

図-6 RBFネットワークの概要

学習効率が高いことは勿論であるが，表-1で示した都市 計画基礎調査データに収録される全 31 種類の建物属性 を入力データ, 出力データをモバイル空間統計で得ら れる入込人口として学習寸ることで，メッシュ内の建 物用途別延床面積の構成パターンと入込人口の関係性 を考慮した分析が可能な点にある. 既存研究では, メ ッシュの入込人口を目的変数, メッシュ内の建物用途 別延床面積を説明変数として, 重回帰分析を行ったが, この場合, 説明変数として選択された各建物用途が入 込人口に与えるインパクトは評価できるものの，メッ シュ内の建物属性の構成パターンは考慮されない。し かしRBFネットワークを用いることでメッシュ内の全て の建物用途別延床面積情報を活かした分析が可能とな る.

\section{(2) 入込人口推定モデル}

RBFネットワークを用いた入込人口推定の概要を図-7 に示寸．まず，3次メッシュスケールにおける建物用途 別延床面積を入力データ, 入込人口を教師データとし て，RBFネットワークの学習を行なう。

中間層のユニット構成については, 著者らの先行研 究12ややび事前のプレ学習の結果を参考にした. 既存研 究では, 2層構造の1層目と2層目のユニット数の比率に ついて，様々なパターンを試したうえで，AIC指標を用 いて「5:3」としている. 本研究では, この比率を参 考にしつつ, プレ学習としてユニット構成を複数回変 更し, 出力データである入込人口と, 教師信号の入込 人口の相関が高くなるように 1 層目を 210 ユニット，2層 目を126ユニットとしてユニット構成を調整した.

入力データとなる建物用途別延床面積のパターンは, 地区毎に大きく異なるため，全地区（110メッシュ）を まとめたモデルでは, 精度が得られないおそれがある. そこで, 建物構成が類似するエリアをクラスタリング し，クラスタ毎にモデルを構築することを考え，建物 用途別延床面積データにクラスタ分析 (ウォード法) 


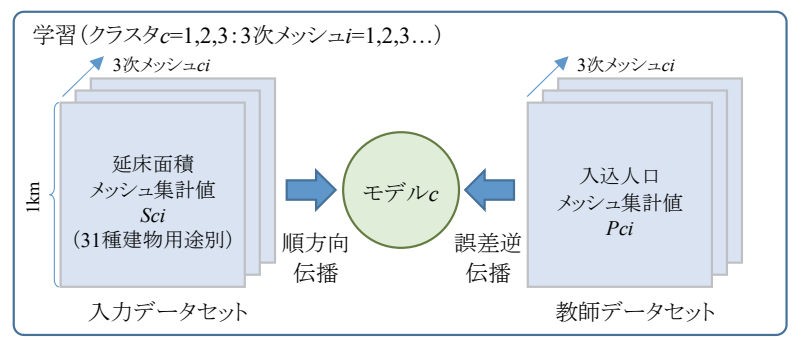

適用 アプローチA(クラスタ $c=1,2,3: 4$ 次メッシュ $i=1,2,3 \ldots$ )
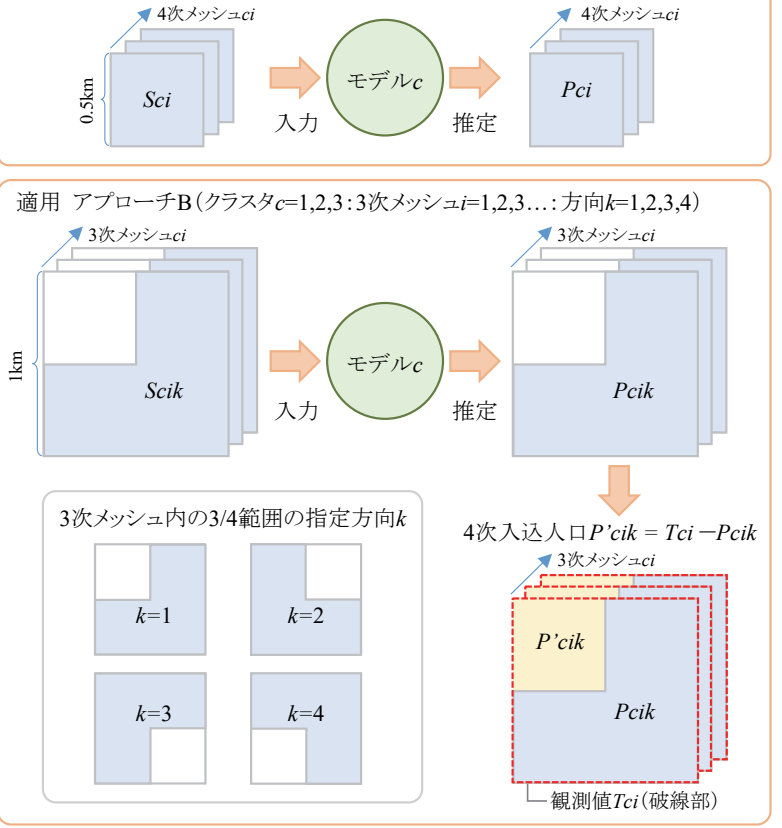

図-7 入込人口推定モデルとダウンスケーリング手順

を適用した. 得られたデンドログラム（図-8）を基に, 学習データ数の確保の面から, クラスタ $1 ， 2 ， 3 の 3 つ$ に区分することとした. 各クラスタの建物用途別の平 均延床面積を図-9に示す. クラスタ1は, 他のクラスタ よりも工業系が多く, 全体の約3割を占めている．クラ スタ2と3は，住宅系が8割以上を占めており，住宅が多 い点に類似点がある。 また，クラスタ 3 は，クラスタ 2 よりも，延床面積の合計が2倍程度あり密度が高いこと， 商業系の割合が比較的大きいことがわかる。これらの クラスタの地理的な分布を図-10に示す．クラスタ毎に おおよそまとまっており, 建物構成の類似性によるエ リアの区分けが見られる.

入込人口の観測值と上記モデルによる推定值の関係 を図-11 に示す．クラスタ 2 では大きく外れるケースが あるものの，全クラスタにおいて，相関係数 は 0.9 を 越えていることから, モデルの学習は収束していると 言える.

\section{（3） 入込人口推定のダウンスケーリング方法}

上記で構築したモデルを用いて，4次スケールの入込 人口を推定する手法を検討する．ここでは，図-7に示す

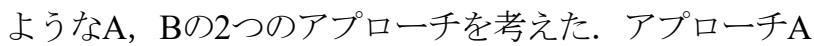

Height

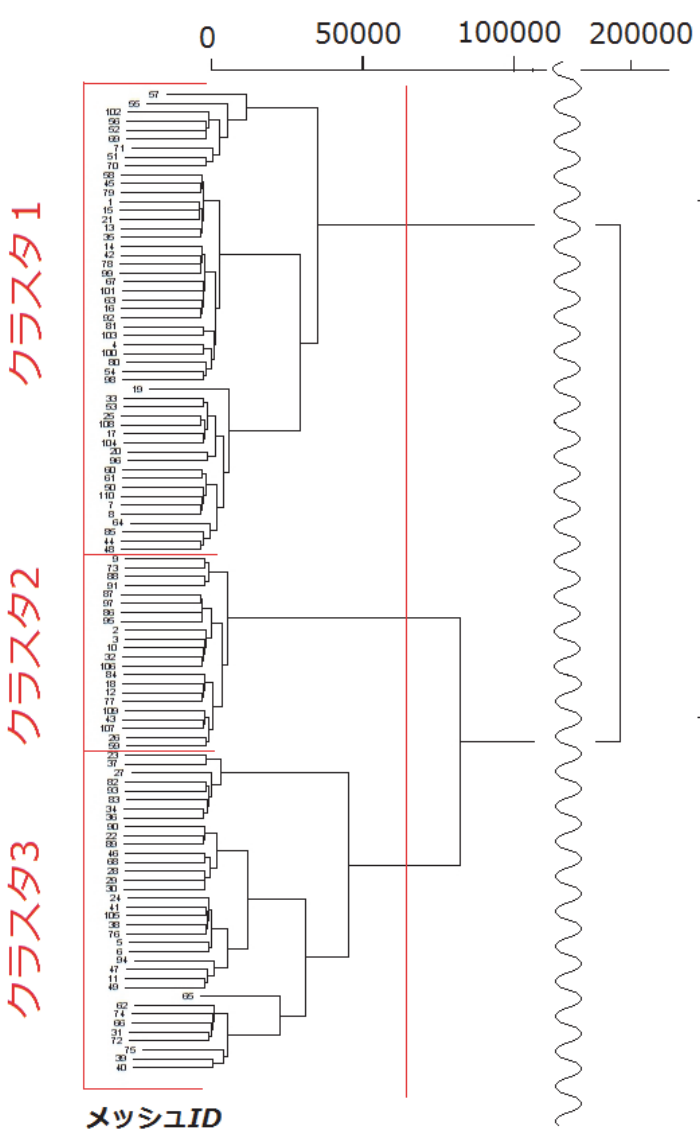

図-8 デンドログラム

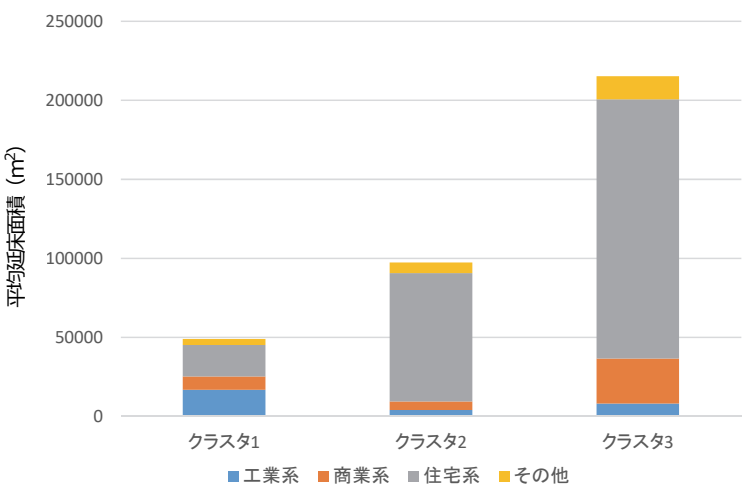

図-9 各クラスタの建物用途別の平均延床面積

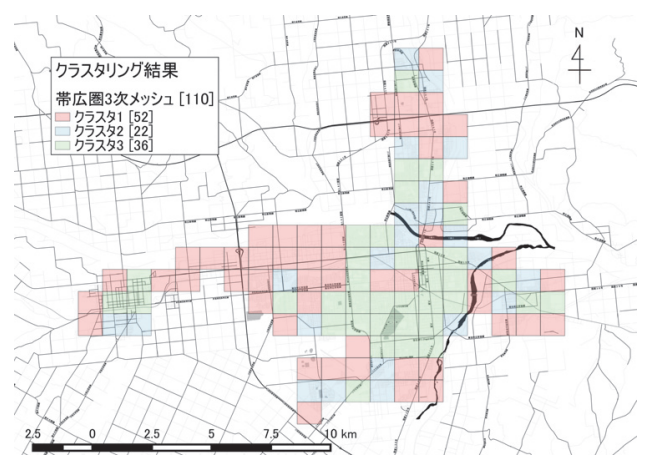

図-10 各クラスタの空間分布 
は，4次メッシュ毎に集計した建物用途別延床面積をモ デルに入力し，各メッシュに応じた入込人口を算出す る直接的な方法である.アプローチBは，3次メッシュ 内の $3 / 4$ の字型の範囲で集計した建物用途別延床面積を モデルに入力し, 得られた入込人口推定值を3次メッシ ユの観測值から差し引いた残りの $1 / 4 の$ 範囲, 寸なわち 対象4次メッシュの入込人口を算出する間接的な方法で ある. 図中の指定方向 $k=1,2,3,4$ のうに上記のL字型の 範囲を $90^{\circ}$ 回転させながら同様の計算を行ない, 3次メッ シュ内の $4 つ の 4$ 次メッシュ範囲の入込人口を網羅的に 算出する.

3 次メッシュで学習した RBF ネットワークを 4 次メ ッシュにダウンスケーリングする問題点として, 3 次メ ッシュの学習データで用いた建物用途別延床面積の最 大值以上，もしくは最小值以下の建物用途別延床面積 が，4 次メッシュの入力データとして使用される可能性， 所謂データの外挿に関する問題が挙げられる.この問 題に対して, 本研究では, クラスタ毎に RBF ネットワ ークによる学習を行うことで 3 次メッシュの建物用途 別延床面積の最大值・最小值の幅をクラスタ毎に揃え た. 3 次メッシュの学習データで用いた全ての建物用途 延床面積の最小值は $0 \mathrm{~m}^{2}$ であること，また，アプロー チBにおいて，入力データの変動幅を $3 / 4$ に抑えたこと から, データの外挿は発生しない.

4 次スケールにおける入込人口の観測值と, アプロー チ A，B による推定值の関係をそれぞれ図-12, 図-13 に示寸. アプローチ A では, クラスタ 2 において誤差 が大きいメッシュが幾つかあるものの，全クラスタに おいて相関係数は約 0.6 以上となった. これに対して, アプローチ B では，相関係数が全てのクラスタで 0.7 を 上回るようになり，アプローチ A よりも精度が向上し ていることが分かる. アプローチ A のように 4 次メッ シュ単位の建物用途別延床面積ではモデルへの入力情 報量が小さくなり推定值が大きくばらつくが，アプロ 一チ B のように 3 メッシュ分に拡大し，入力情報量を 元の 3 次スケールに近づけることで，そのようなばら つきが抑制されたと考えられる.

これらのアプローチの妥当性を検証するため，まず は, 4 次スケールの入込人口観測值の空間的分布を図14 に示寸．観測值の分布を見ると，3 次スケールでの 分布（図-5）と同じ傾向となるが，3 次メッシュの中で の入込人口の大小が分かり, より高解像度の分析が可 能となる. 例えば，特に商業系地域においては，3 次ス ケールでは入込人口が大きいメッシュでも，4 次にダウ ンスケールすると人口が等分されるケース，偏りが生 じるケースが存在する，後者のケースについては，平 日 10 時における JR 帯広駅の近辺や工業系エリアなど への人の集中を意味する. このような細かいメッシュ

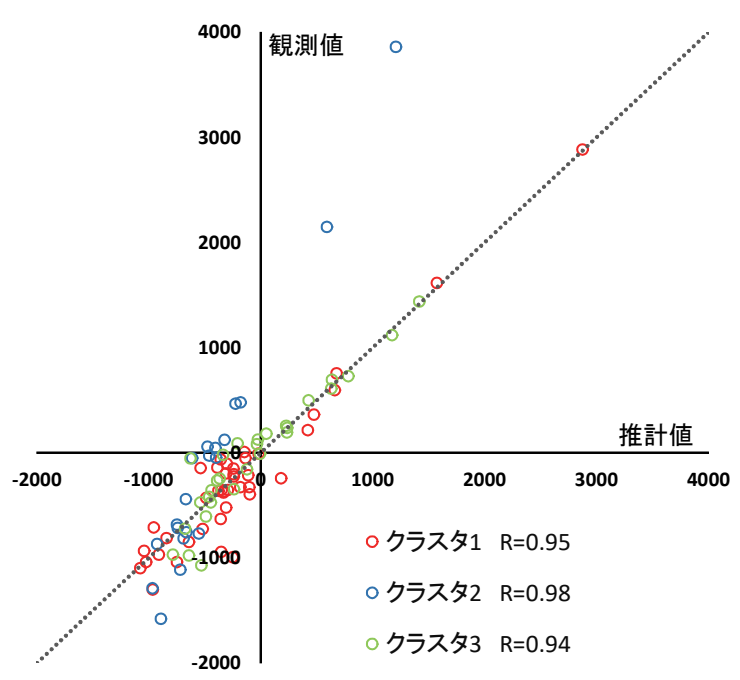

図-11３次スケールにおける各クラスのモデル精度

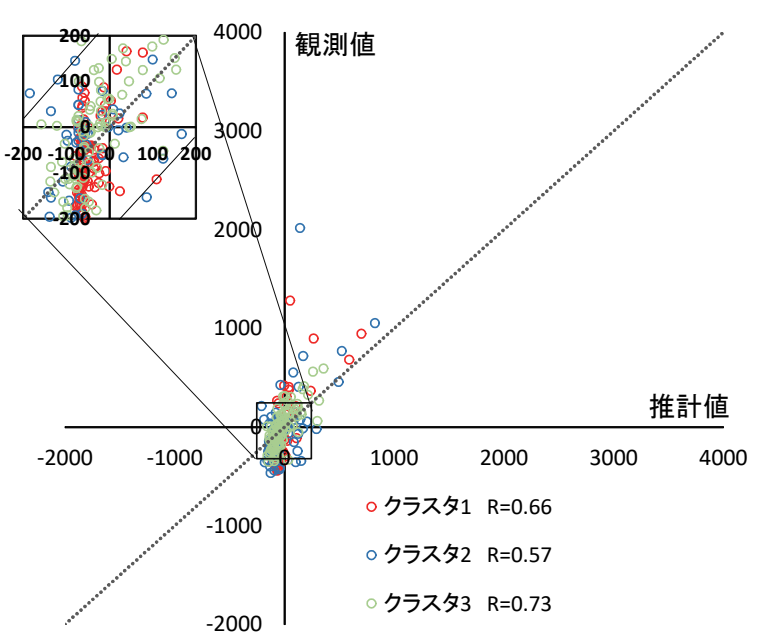

図-12 アプローチAによる入込人口推定の精度

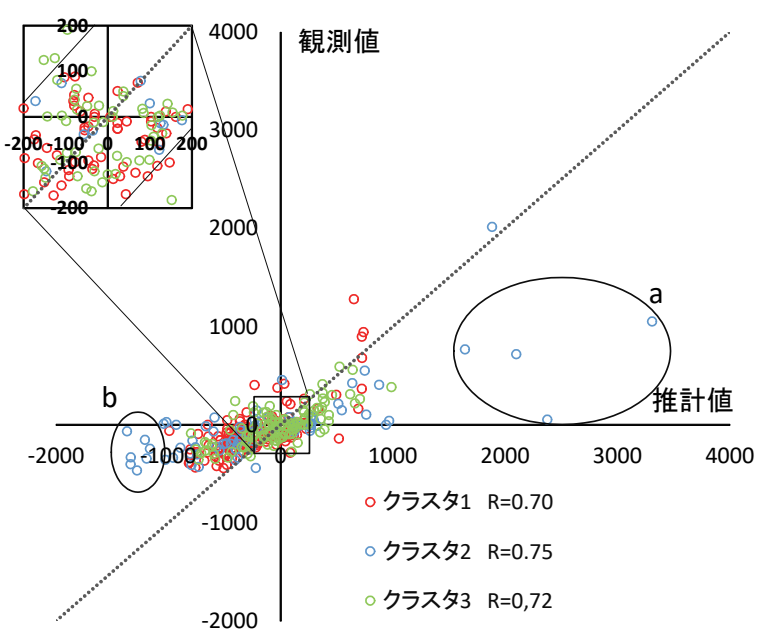

図-13 アプローチBによる入込人口推定の精度 
単位での入込人口の可視化により建物立地との比較な どを高い空間分解能で把握, 分析することが可能とな る.

次に，アプローチ A， B による入込口推計值の分布を 図-15，図-16 にそれぞれ示す，アプローチA では，入 込人口の大小の幅が観測值よりも小さく, 地区毎, メ ッシュ毎のメリハリが若干把握しづらい。一方，アプ ローチ B では, アプローチ A よりも, 推定值の範用が 大きくなり，観測值と類似した分布を示している．図13, 図-14 において示した通り, アプローチ B の方が 高い相関が得られていることからも，今後，他の都市 への適用や将来推計などを行う際には，アプローチ B を採用することが良いと言える。

以上のように，モデルの空間的な適用範囲を工夫す ることでより細かいスケールでの入込人口推定を可能 とする手法を開発した。 この手法を用いることで，個 人情報秘匿等によってデータ取得が困難となる細かい スケール（4 次よりも小さいスケールも含む）でも，入 込人口を算出することが可能となる.ただし，モデル 自体の精度については, 相関係数 0.7 程度と十分とは言 い難い。これについては, 入力データに他の情報, 例 えば建物自身の情報だけではなく周辺の建物や交通市 ットワーク，地形などのデータを加えることで解決で きると思われる.

また，図-12，図-13 では，人口が少ないメッシュの プロットが重なっているため, その部分を拡大した図 を同図に挿入した．これらのプロットを見るとばらつ きは大きいが，その誤差（推計值と観測值の差分）は \pm 150 人程度に収まるメッシュがほとんどである. 本モ デルの目的は，入込人口（夜間人口との差分）を推定 し，その動きの大きい箇所を把握することであるため, 上記のような值の小さい範囲における誤差は大きな問 題ではない. しかしながら, アプローチBのクラスタ 2 における大きな誤差については, 今後の改善のために, 当該メッシュの建物用途の構成を調べ，原因について 考察を行った. 図-13 の a のメッシュについては, 当該 メッシュが帯広駅前であり, 商業施設が他の箇所より も圧倒的に多いため, 入込人口が過剩に推計されたと 考えられる. 逆に, b のメッシュでは, 商業施設がほと んどなく, 過小な推計になったと考えられる. 本研究 では, モデルの精度向上のため, 建物用途の構成の類 似性からメッシュをクラスタリングし，そのクラスタ 毎にモデルを構築するという工夫をこらしたが，クラ スタ 2 については, 上記のような極端なメッシュを含 んでしまったため, 誤差が大きいケースが生じた.こ の解決策としては, 規模の大きい都市を対象とし, 建 物構成の偏りが小さくなるようにクラスタリングを行 ない，モデルを再構築することが有効と考えられる.

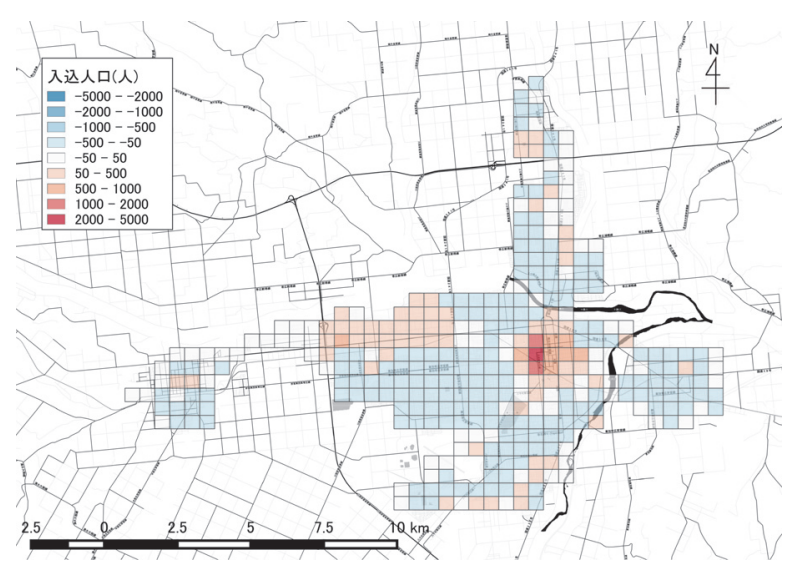

図-14 入込人口観測值の分布 (4 次スケール)

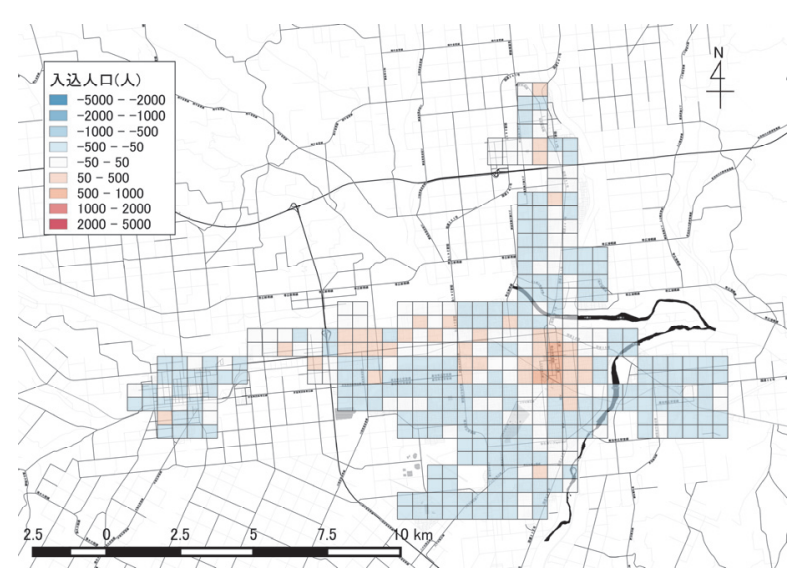

図-15 アプローチAによる入込人口推定值の分布

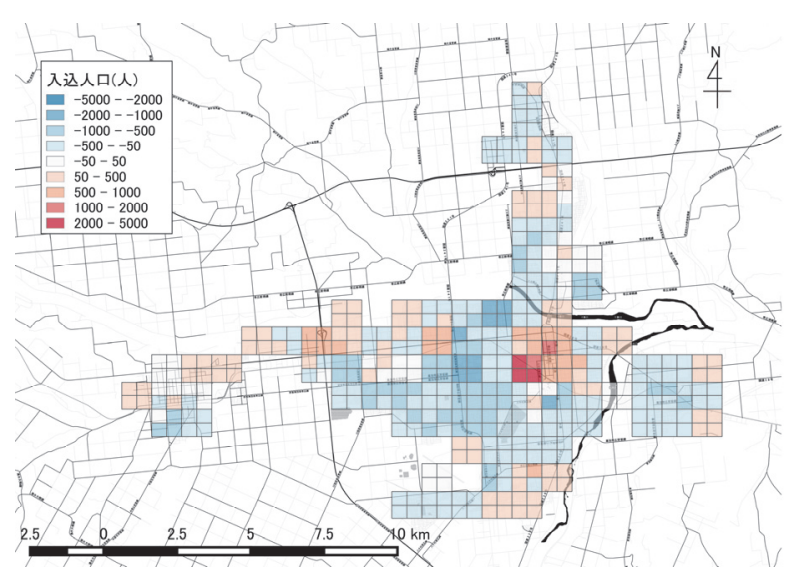

図-16 アプローチ B による入込人口推定值の分布

以上のような解決を行ない，さらなる精度向上を目指 したい. 


\section{4. 結論}

本研究では，都市計画基礎調査とモバイル空間統計 の 2 つのマイクロジオデータに RBF ネットワークを適 用して, 建物用途別（31 種）延床面積から対象時間帯 の入込人口を推定するモデルを構築するとともに，推 定をより細かい空間単位で行うダウンスケーリング手 法を開発した，得られた結論を以下に示す.

・全地区をまとめたモデルでは，地区ごとに建物分布が 異なるため精度が得られないおそれがある。 そこで， 対象地域の建物構成の類似性からメッシュを 3 つのク ラスタに類型化した。

・ 上記のクラスタ別に，建物用途別延床面積を入力，入 込人口を教師データとして, RBF ネットワークモデル の学習を行った. 観測值と推定值の相関係数は 0.9 以 上を示し，学習が適切に収束したことが確認された.

・得られたモデルを用いて，4 次メッシュで集計した建 物用途別延床面積から直接的に各メッシュの入込人口 を算出するアプローチ A，3 次メッシュの入込人口観 測值から $3 / 4$ 範囲の入込人口推定值を差し引くアプロ 一チB の 2 つのダウンスケーリング方法を提案した.

- 推定值と観測值の相関係数を求めたところ, アプロー チ A では 0.6 程度, アプローチ B では 0.7 を上回る結 果が得られた. さらに, 推定值を空間的に可視化し, 観測值との比較を行った結果, アプローチ A，B とも に観測值と同様な分布が得られた．特に，アプローチ B では，高い相関性からも他都市や将来推計に用いる ことができると言える.

本研究では, 先行研究や事前学習の成果を基に, RBF ネットワークの中間層パターンを「5:3」の比としたが, 今後は，このようなハイパーパラメータのチューニン グを行うとともに，様々な入力データを加え，モデル 自体の精度を向上させる。また，他の地域，他の時間 帯（季節，週）でも同じアプローチで適切なダウンス ケーリングができるかを検証する必要がある。これら を解決できれば，都市構造を変化させた場合の時間毎 に変化する入込人口を推定でき，それを時空間的に可 視化することで，コンパクトシティ・プラス・ネット ワーク施策等を検討するための有用な情報を創りだす ことが可能となる.
謝辞 : 本研究は Japan Science and Technology Agency (JST), e-ASIA Joint Research Program の助成を受けた。ここに記 して感謝の意を表する.

\section{参考文献}

1) 国立社会保障 - 人口問題研究所, http://www.ipss.go.jp /syoushika/tohkei/Mainmenu.asp (2016 年 4 月閲覧)

2）鈴木温, 宮之上達也, 杉田篤志 : マイクロシミュレ ーションモデルを用いた都市の人口分布・世帯構造 変化予測, 土木計画学研究・講演集, Vol. 53, CDROM, pp. 2920-2926, 2016.

3) 鈴木温, 杉木直, 宮本和明 : 空間的マイクロシミュ レーションを用いた都市内人口分布の将来予測, 都 市計画論文集，Vol. 51, No. 3, pp. 839-846, 2016.

4) 杉木直, 柏村昆也, 大谷紀子, 宮本和明 : 郊外二ュ ータウンにおける世帯マイクロシミュレーションの 適用, 土木計画学研究・講演集, Vol. 53, CD-ROM, pp. 2910-2919, 2016.

5) NTT Docomo ホームページ「モバイル空間統計に関 する情報」， http://www.nttdocomo.co.jp/corporate/ disclosure/mobile_spatial_statistics (2015.4閲覽)

6) 有村幹治, 鎌田周, 浅田拓海 : マイクロデータの統 合化による建物用途別メッシュ入込人口の推計, 土 木学会論文集 D3（土木計画学），Vol. 72, No. 5, pp. I 515-I-522, 2016.

7) 国土交通省都市局都市計画課都市計画調查室「都市 計画基礎調查データ分析例（案）」, https://www.mlit. go.jp/toshi/tosiko/kisotyousa99.html (2015.4閲覧)

8) 携帯電話・PHS 契約者数 : 一般社団法人電気通信事 業者協会，http://www.tca.or.jp/database/（閲覧日： 2017 年 7 月 4 日)

9) 㴊田孝康, 前原正和, 森邦彦, 村島定行 : 教科学習 的手法を用いた RBF ネットワークの学習, 電子情報 通信学会技術研究報告 NC, Vol. 99, No. 684, pp. 157$163,2000$.

10) Moody, J. and Darken, C. J. : Fast learning in networks of locally-tuned processing units, Neural Computation, Vol. 1, No. 2, pp. 281-294, 1989.

11) 八野智博, 松本雅裕, 高田等: RBF ネットワークと 免疫的アルゴリズムによる非線形システムのオンラ イン同定法, 鹿児島大学工学部研究報告, Vol. 47, pp. 27-34, 2005 .

12）浅田拓海, 岡田和洋, 松田真宜, 有村幹治 : RBF ネ ットワークによるコミュニティサイクル利用動態の 短期予測, 土木学会論文集 D3 (土木計画学) , Vol. 71, No. 5 (土木計画学研究・論文集第 32 巻), pp. I 425 -I $431,2015$.

(2017. 2. 24 受付) 


\section{DEVELOPMENT OF DOWNSCALING METHOD FOR THE HOURLY POPULATION INFLOW ESTIMATION BY USING RBF NETWORK}

\section{Takumi OGOSHI, Mikiharu ARIMURA and Takumi ASADA}

Recently, in order to obtain the planning information such as a compact city policy, the use of microgeo data has been applied effectively. In this study, we develop a method to estimate the hourly population inflow during downscaling the spatial analysis resolution by using the RBF Network with respect to the two mobile data of the mobile spatial statistics and the urban planning basic survey. In this study, a model is formulated that estimates the population inflow of each mesh from the total floor space by building application counted on the regional mesh level 3 (1 km square grid) scale for estimating the population on the regional mesh level $4(500 \mathrm{~m}$ square grid) scale. According to the spatial visualization of the obtained population distribution by this method, it can grasp the distribution of population easily in which it is better than estimating with 3rd scaling. 